\title{
FBXW7-mutated colorectal cancer cells exhibit aberrant expression of phosphorylated-p53 at Serine-15
}

\author{
Ningning $\mathbf{L i}^{1,2, *}$, Federica Lorenzi ${ }^{1, *}$, Eliana Kalakouti ${ }^{1,3, *}$, Makhliyo Normatova $^{1}$, \\ Roya Babaei-Jadidi ${ }^{1}$, Ian Tomlinson ${ }^{4}$, Abdolrahman S. Nateri ${ }^{1}$ \\ ${ }^{1}$ Cancer Genetics \& Stem Cell Group, Cancer Biology Unit, Division of Cancer and Stem Cells, School of Medicine, University \\ of Nottingham, Nottingham NG7 2UH, UK \\ ${ }^{2}$ Department of Neurodegenerative Disease, Institute of Neurology, University College London, London WC1N 3BG, UK \\ ${ }^{3}$ Hillingdon Hospital, Uxbridge UB8 3NN, UK \\ ${ }^{4}$ Molecular and Population Genetics Laboratory, the Wellcome Trust Centre for Human Genetics, University of Oxford, Oxford \\ OX3 7BN, UK \\ *These authors have contributed equally to this work
}

Correspondence to:

Abdolrahman S. Nateri, e-mail: a.nateri@nottingham.ac.uk

Keywords: FBXW7, phopsho-P53(Ser15), colorectal cancer, drug resistance, CK la

Received: December 24, $2014 \quad$ Accepted: February 05, $2015 \quad$ Published: March 16, 2015

\section{ABSTRACT}

FBXW7 mutations occur in a variety of human cancers including colorectal cancer (CRC). Elucidating its mechanism of action has become crucial for cancer therapy; however, it is also complicated by the fact that FBXW7 can influence many pathways due to its role as an E3-ubiquitin ligase in proteasome degradation. FBXW7 and TP53 are tumour suppressors intensively implicated in colorectal carcinogenesis. Deletion mutations in these two genes in animal models mark the progression from adenoma to carcinoma. Although still largely unknown, the last defense mechanism against CRC at the molecular level could be through a synergistic effect of the two genes. The underlying mechanism requires further investigation. In our laboratory, we have used a phospho-kinase profiler array to illustrate a potential molecular link between FBXW7 and p53 in CRC cells. In vitro and in vivo assessments demonstrated aberrant induction of phosphorylated p53 at Serine 15 [phospho-p53(Ser15)] in human FBXW7-deficient CRC cells as compared to their FBXW7-wild-type counterparts. FBXW7 loss in HCT116 cells promoted resistance to oxaliplatin. Immunoblotting data further confirmed that reduction of phospho-p53(Ser15) may contribute to the decreased efficacy of therapy in FBXW7-mutated CRC cells. The findings may suggest the applicability of phospho-p53(Ser15) as an indicative marker of FBXW7-mutations. Phospho-p53(Ser15) regulation by FBXW7 E3-ligase activity could provide important clues for understanding FBXW7 behavior in tumour progression and grounds for its clinical applicability thereafter.

\section{INTRODUCTION}

FBXW7 (F-box and WD repeat domaincontaining 7, also known as FBW7, AGO, SEL10, CDC4) and TP53 are widely-known tumour suppressors and their genetic alterations lead to malignant transformation, metastatic spread and poor survival of cancer sufferers [1-4]. They are among the most commonly mutated genes after K-RAS and APC in colorectal cancer (CRC) [5-7].
FBXW7 constitutes one of the four subunits of SCF (SKP1cullin-F-box)-E3 ubiquitin protein ligase complex, which functions in phosphorylation-dependent ubiquitination. To date, a wide array of $\mathrm{SCF}^{\mathrm{FBXW}}$ E3-ligase substrates have been identified and characterized, including cyclin E $[8,9]$, c-Myc [10, 11], c-Jun [12, 13], Notch [14], Presenilin [15], SREBP [16], Aurora-A [17], Krüppel-like factor 5 (KLF5) [18], DEK proto-oncogene [19], and peroxisome proliferator-activated receptor- $\gamma$ coactivator- $1 \alpha(\mathrm{PGC}-1 \alpha)$ 
[20]. These and several other $\mathrm{SCF}^{\mathrm{FBXw} 7} \mathrm{E} 3$-ligase substrates play central roles in cell division, growth, differentiation, cell-fate determination and maintenance of the phenotype of a variety of types of stem cells [3, 21-24]. There are several comprehensive reviews on FBXW7 functions as an E3-ligase in ubiquitin mediated proteasome-degradation [1, 3, 8-14].

Recent literature has reported the synergistic contribution of FBXW7 and TP53 to the suppression of gastrointestinal cancer $[15,16]$. FBXW7 has been identified as a transcriptional target of TP53 and lower expression levels of FBXW7 upon TP53-mutations have been reported $[15,17,18]$. Parallel loss of the two tumoursuppressors was found to cooperate in tumourigenesis [16, $18,19]$. In line with such data, is the fact that most natural FBXW7 mutations in cancers are shown to exhibit a TP53 mutation $[6,7,18]$. Despite previous reports that FBXW7 is transcriptionally controlled by p53, little is known about their synergistic involvement in the molecular etiology of CRC. The p53-dependent relationship, reported in current literature, does not fully reveal the interplay between p53 and FBXW7, and p53 activity modulated by FBXW7dependent mechanism(s) is yet unidentified.

Considering the multiple challenges to treatment response posed by a mutated tumour suppressor gene, elucidating FBXW7's mechanisms of action could be a breakthrough for cancer therapy. More recently, a number of groups demonstrated FBXW7-mediated drug resistance in human cancer cell lines via FBXW7suppression and increased levels of pro-survival factor MCL1 and mTOR [20-23]. Wang et al. showed that loss of FBXW7 leads to rapamycin drug-resistant by inducing Epithelial-Mesenchymal Transition (EMT) in CRC cells [21]. However, it is still unclear whether this mechanism explains FBXW7 loss-conferred resistance to other standard chemotherapeutics such as 5-fluorouracil (5-FU), cisplatin and oxaliplatin.

Ultraviolet (UV) and DNA damage agents induced protein phosphorylation is one of the earliest events in modifying protein stability, and FBXW7 E3-ligase mediates the degradation of proteins in a phosphorylationdependent manner [1, 3, 8, 24]. FBXW7 influences many pathways due to its role as an E3-ligase in proteasomedegradation. Loss of FBXW7 function is likely to result in failed regulation of its downstream targets and cellular acquisition of the hallmarks of cancer.

This study investigated the relationship between deregulation of FBXW7 E3-ligase activity and p53 phosphorylation. Our data show aberrant induction of phosphorylated-p53 at Serine 15 [phospho-p53(Ser15)] in human CRC cells that lacked FBXW7 as compared to their FBXW7 wild-type counterparts. TP53 is a key player in determining the response of colorectal cancer cells to oncogenic stress and chemotherapy by oxaliplatin and 5-FU [25]. UV-radiation but not oxaliplatin drug induced phospho-p53(Ser15) in CRC cells with FBXW7 deletion.
Despite the accumulation of phospho-p53(Ser15) in mutant-FBXW7 CRC-tissues, FBXW7 does not directly interact with phospho-p53(Ser15) for degradation. Posttranslational modification of p53 by its phosphorylation on Serine 15 has been one of the most extensively studied functional switch mechanisms in response to genotoxic stress. Serine 15 residue of p53 is phosphorylated allowing p53 to be released from its normal physiological function $[26,27]$. Subsequently, p53 stabilizes in the nucleus to act as a transcriptional activator for tumour suppression, implicating phospho-p53(Ser15) as a marker of FBXW7associated carcinogenesis.

\section{RESULTS}

\section{FBXW7 loss leads to induction of p53-phosphorylation at Serine-15}

Ablation of FBXW7 was shown to elevate the level of phosphorylated-substrate protein and its downstream signaling proteins. Such a phenomenon could inform about the disease mechanisms of colorectal carcinogenesis and the cellular pathways affected by homeostatic deregulation caused by an FBXW7 mutation. Posttranslational modification of p53 by phosphorylation may be an important mechanism underlying regulation of p53 stabilization and function. However, the molecular and cellular mechanisms that link FBXW7 and p53 following phosphorylation are unclear. An in vitro human phosphokinase array (HPKPA) with multiple p53-phosphoacceptor sites (Figure 1A), was used to assess changes to the protein phosphorylation profile. We and others have reported that HCT116 and DLD-1 cell-lines harboring wild-type FBXW7; $F B X W 7(+/+)$, or inactivated FBXW7; $F B X W 7(-/-)$, have the characteristics of human CRC cells without or with FBXW7-mutation [19, 20, 23, 28]. In particular, they provide an excellent in vitro model to delineate the molecular mechanisms that contribute to neoplasia. Remarkably, in the absence of FBXW7, both HCT116 and DLD-1 showed a substantial increase in p53 phosphorylation at Serine-15 as compared to control cells (Figure 1F), while phosphorylation at Serine-46 and Serine-392 remain unchanged (Figure 1, 1B vs. 1D and 1C vs. 1E). Western blot analysis showed an increase of p53 phosphorylated at Ser-15 in $F B X W 7(-/-)$ versus wild-type FBXW7(+/+) (Figure 1G).

The Ser15 phosphorylation site is evolutionarily conserved and corresponds to Ser18 of murine p53, which has not been as extensively examined as that of human p53. Mice harbouring an fbxw7 allele in which exon5 was flanked by two loxP sites were crossed to villin-cre transgenic mice as previously described [28, 29] (Figure 2A). We examined p53 phosphorylation in mouse intestinal tissues harboring $f b x w 7$ deletion. We detected enhanced phosphorylation of p53 at Serine-18 
A

\begin{tabular}{|c|c|c|c|c|c|c|c|c|}
\hline & 1 & 2 & 3 & 4 & 5 & 6 & 7 & 8 \\
\hline a & & & $\begin{array}{c}\text { p53 } \\
(\mathrm{S} 392)\end{array}$ & $\begin{array}{c}\text { p53 } \\
\text { (S392) }\end{array}$ & & & P.C & P.C \\
\hline b & $\begin{array}{l}\text { AKT } \\
\text { (T308) }\end{array}$ & $\begin{array}{l}\text { AKT } \\
(\text { (T308) }\end{array}$ & $\begin{array}{l}\text { p53 } \\
\text { (S46) }\end{array}$ & $\begin{array}{l}\text { p53 } \\
\text { (S46) }\end{array}$ & & & & \\
\hline c & $\begin{array}{l}\text { p70 S6 } \\
\text { (T389) }\end{array}$ & $\begin{array}{l}\text { p70 S6 } \\
\text { (T389) }\end{array}$ & $\begin{array}{r}\text { p53 } \\
(\mathrm{S} 15) \\
\end{array}$ & $\begin{array}{r}\text { p53 } \\
\text { (S15) }\end{array}$ & $\begin{array}{c}\text { p27 } \\
(\mathrm{T} 198) \\
\end{array}$ & \begin{tabular}{|c|}
$\mathbf{p 2 7}$ \\
$(\mathrm{T} 198)$ \\
\end{tabular} & $\begin{array}{c}\text { Paxillin } \\
\text { (Y118) }\end{array}$ & \begin{tabular}{|c|}
$\begin{array}{c}\text { Paxillin } \\
\text { (Y118) }\end{array}$ \\
\end{tabular} \\
\hline d & $\begin{array}{c}\text { p70 S6 } \\
\text { (T421/S424) }\end{array}$ & $\begin{array}{c}\text { p70 S6 } \\
(\text { T421/S424) }\end{array}$ & $\begin{array}{c}\text { RSK1/2/3 } \\
\text { (S380) }\end{array}$ & $\begin{array}{c}\text { RSK1/2/3 } \\
\text { (S380) }\end{array}$ & $\begin{array}{c}\text { p27 } \\
\text { (T157) }\end{array}$ & $\begin{array}{c}\text { p27 } \\
(\mathrm{T} 157)\end{array}$ & $\begin{array}{c}\text { PLCy-1 } \\
\text { (Y783) }\end{array}$ & $\begin{array}{l}\text { PLCy-1 } \\
\text { (Y783) }\end{array}$ \\
\hline e & $\begin{array}{l}\text { p70 S6 } \\
\text { (T229) }\end{array}$ & $\begin{array}{l}\text { p70 S6 } \\
\text { (T229) }\end{array}$ & $\begin{array}{c}\text { RSK1/2 } \\
\text { (S221) }\end{array}$ & $\begin{array}{c}\text { RSK1/2 } \\
\text { (S221) }\end{array}$ & $\begin{array}{l}\text { c-Jun } \\
\text { (S63) }\end{array}$ & $\begin{array}{l}\text { c-Jun } \\
\text { (S63) }\end{array}$ & $\begin{array}{l}\text { Pyk2 } \\
\text { (Y402) }\end{array}$ & $\begin{array}{l}\text { Pyk2 } \\
\text { (Y402) }\end{array}$ \\
\hline$f$ & $\begin{array}{l}\text { STAT1 } \\
\text { (Y701) }\end{array}$ & $\begin{array}{l}\text { STAT1 } \\
\text { (Y701) }\end{array}$ & $\begin{array}{l}\text { STAT4 } \\
\text { (Y693) }\end{array}$ & $\begin{array}{l}\text { STAT4 } \\
(\text { Y693) }\end{array}$ & $\begin{array}{l}\text { eNOS } \\
\text { (S1177) }\end{array}$ & $\begin{array}{l}\text { eNOS } \\
\text { (S1177) }\end{array}$ & $\begin{array}{l}\text { N.C } \\
\text { (PBS) }\end{array}$ & $\begin{array}{l}\text { N.C } \\
\text { (PBS) }\end{array}$ \\
\hline
\end{tabular}

B

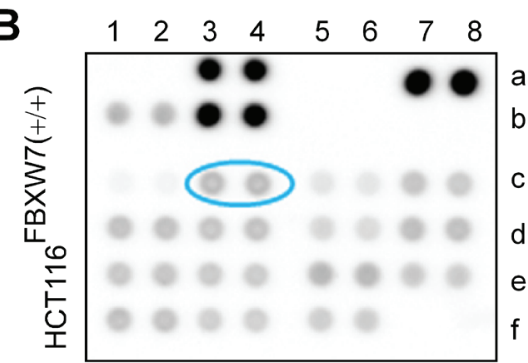

D

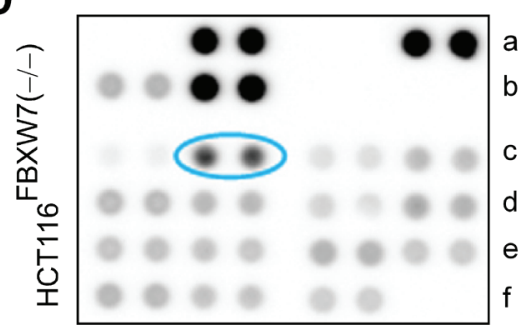

c

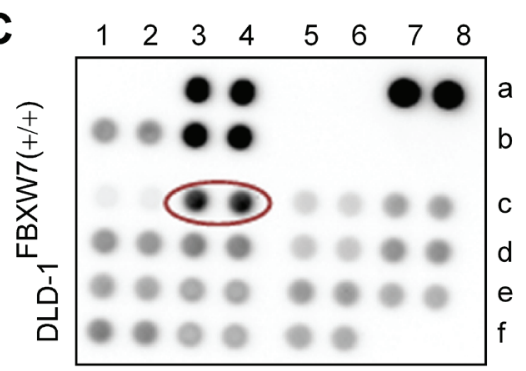

E

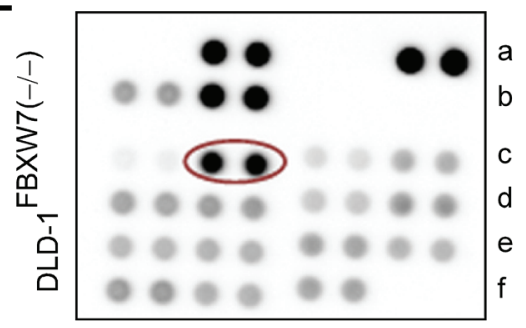

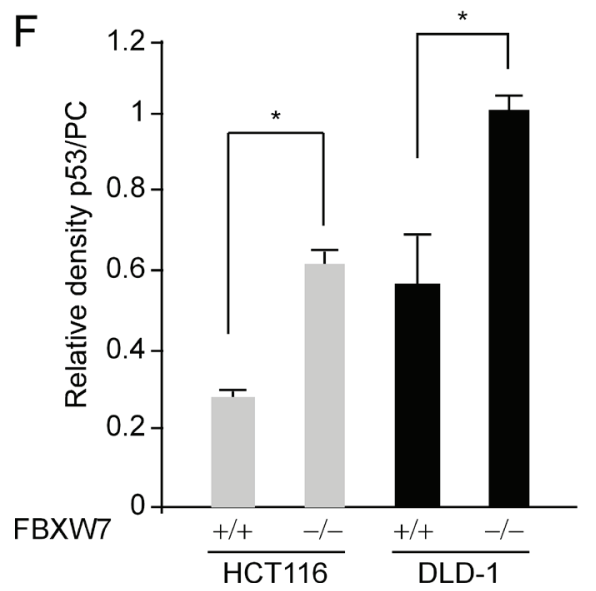

G

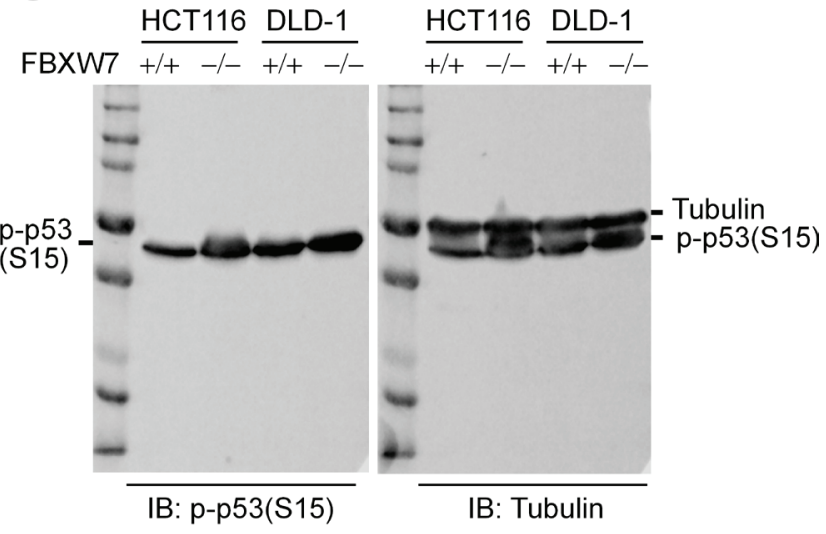

Figure 1: Human phospho-kinase-profiler-array (HPKPA) revealed induction of phospho-p53(Ser15) in FBXW7-null human CRC cells [FBXW7(-/-) vs. FBXW7(+/+)]. A. Schematic representation of the coordinates of the pre-coated phosphospecific antibodies in duplicate in a nitrocellulose-membrane. Dashed red-circle highlights the antibody position for phospho-p53(Ser15). B-E. Outcome overview of the HPKPA using human CRC-cells expressing and lacking FBXW7; FBXW7-deficient HCT116 (D) and DLD-1 (E) cells [FBXW7(-/-)], compared to parental HCT116 (B) and DLD-1 (C) cells [FBXW7(+/+)]. F. The expression of phosphop53(Ser15) protein was significantly increased. Scanned values obtained using transillumination scanner of phospho-p53(Ser15) and Positive Controls (PCs) spots as corresponding to HCT116 and DLD-1 cell lines in B-E. The results shown are representative of experiments performed at three independent times. G. Phospho-p53(Ser15) expressions was analyzed by Western blotting analysis. Protein extracts isolated from HCT116 and DLD-1 cell lines with FBXW7(-/-) and FBXW7(+/+) alleles were Western blotted for phospho-p53(Ser15) antibody and Tubulin (loading control). 

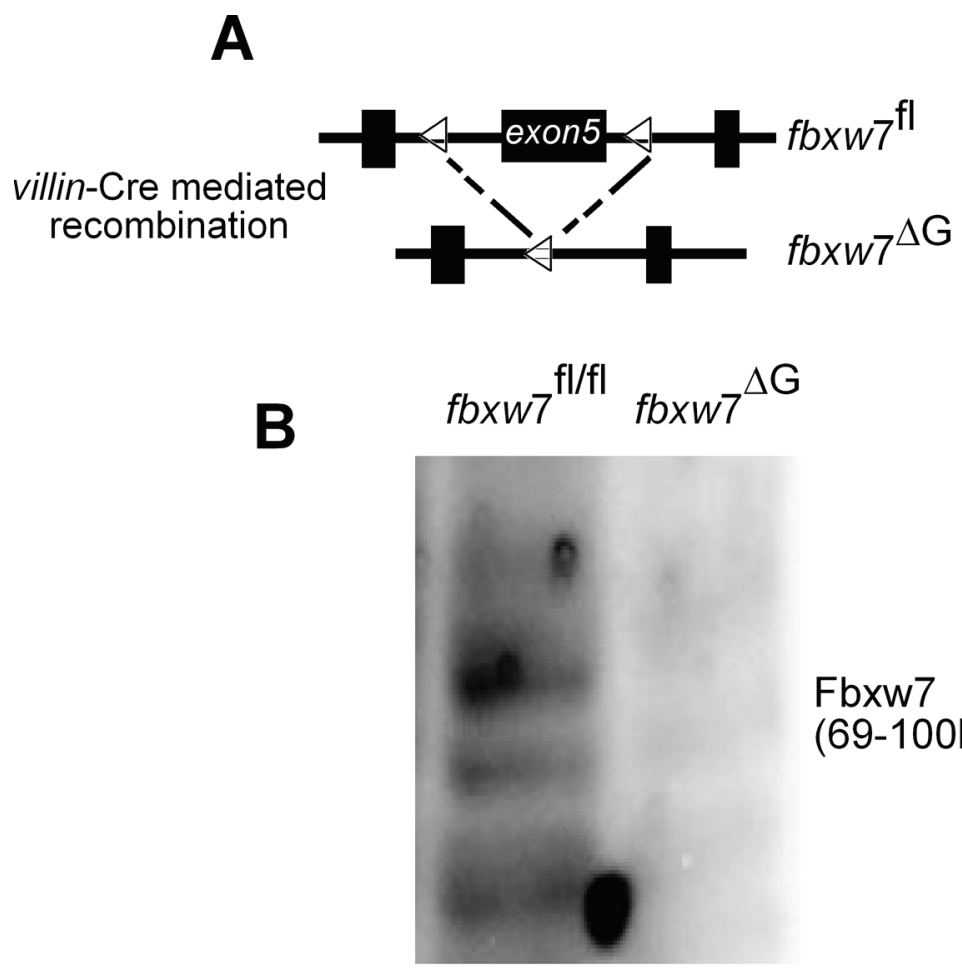

Fbxw7

$(69-100 \mathrm{kDa})$

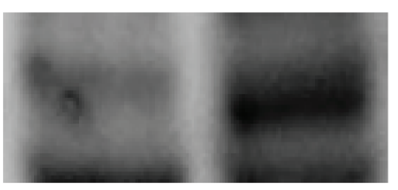

Phospho-p53 (S18)

(mouse)

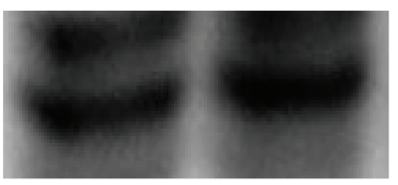

p53

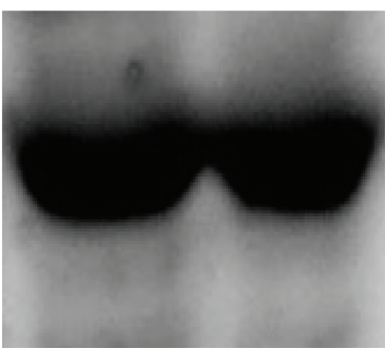

$\beta$-actin

Figure 2: Induction in the level of the of murine phospho-p53(Ser18) in the intestine of fbxw7 ${ }^{\Delta G}$ mice. A. Schematic shows the floxed Fbxw7 allele $\left(f b x w 7^{\mathrm{t} / \mathrm{fl}}\right)$ before and after villin-Cre recombination to generate gut-specific conditional Fbxw7 inactivation $\left(f b x w 7^{\Delta \mathrm{G}}\right)$ mice. B. Western blot analysis of $f b x w 7^{\mathrm{fl} / \mathrm{ll}}$ and $f b x w 7^{\Delta \mathrm{G}}$ intestinal proteins using antibodies against Fbxw7, p53, phosphop53(Ser15), and the loading control $\beta$-actin. Experiments were performed on at least two independent occasions.

with the phospho-specific p53 (Ser15) antibody [30]. Phosphorylation of Serine-18 regulates distinct p53 functions in mice, including p53-dependent transcripton, apoptosis, and cell cycle arrest after DNA damage [30]. There was accumulation of phosphorylated p53 at Serine-18 but despite the high levels of phospho$\mathrm{p} 53$ (Ser18), there was only a very small increase in total levels of p53 (Figure 2B).

\section{FBXW7-dependent induction of phospho- p53(Ser15) in CRC cells treated with UV radiation}

FBXW7 is involved in the control of genetic instability $[16,19]$. A strong association has been found between phosphorylation of $\mathrm{p} 53$ on Serine- 15 and exposure to UV irradiation [31,32]. In order to evaluate 
phospho-p53(Ser15) induction's dependence on FBXW7 in UV-treated CRC cells, we used HCT116 cells harboring wild-type and inactivated FBXW7. Immunofluorescence (IF) staining showed nuclear phospho-p53(Ser15) was almost undetectable in control HCT116 $6^{\mathrm{FBXW} 7(++)}$ cells, but was markedly increased in FBXW7-null HCT116 $6^{\mathrm{FBXW} 7(--)}$ cells (Figure 3, 3E vs. 3B; $3 \mathrm{~F}$ vs. $3 \mathrm{C}$ and $3 \mathrm{M}$ ). This finding was supported by Western blot (WB) analysis (Figure $3 \mathrm{~N}$ ). In addition, we applied UV-treatment to the HCT116 cells to provide clearly distinguishable results. Treatment with UV-radiation enhanced phospho-p53(Ser15) induction in both the wild-type and FBXW7-mutated cells (Figure 3, $3 \mathrm{H} \& 3 \mathrm{~K}$; 3M, right panel). Nonetheless, phosphop53(Ser15) in HCT116 ${ }^{\mathrm{FBXW7(-/)}}$ cells was markedly higher than that in HCT116 $6^{\mathrm{FBXW} 7(++)}$ cells, with both cytoplasmic and nuclear localization (Figure 3, 3K vs. 3H; 3L vs. 3I). The WB data were consistent with the IF results (Figure 3, $3 \mathrm{M}$ and $3 \mathrm{~N}$ ). Our results validated the enrichment of phospho-p53(Ser15)-induction in FBXW7-deficient CRC cell lines. Subsequently we further investigated whether phospho-p53(Ser15) could provide diagnostic and/or prognostic value for CRC-biopsies with FBXW7mutations.

\section{Phospho-p53(Ser15) protein accumulation in human CRC-tissues with FBXW7-mutation}

We carried out in vivo investigations to validate the phospho-p53(Ser15) induction in CRC tissues excised from patients with FBXW7-mutated tumours. Immunohistochemical (IHC) comparison of phosphop53(Ser15) expression in wild-type and FBXW7-mutated human CRC-tissue was carried out. The intensity of the IHC staining observed in the two tissue types (wildtype vs. mutants for FBXW7), was evaluated in a semiquantitative manner. In CRC tissues, the architecture of the gut wall was chaotic as expected for both cancer specimens: $F B X W 7$ - wild-type (control) and -mutant (Figure 4, 4C-4F). Irregular and distorted crypts were evident invading the submucosal area of CRC tissues (Figure 4E, 4F). Expression of phospho-p53(Ser15) protein was completely lost in $F B X W 7$ wild-type tissue (Figure 4C, 4D) [mean staining-score; 0.33 (Figure 5A)], irrespective of the tumour-type or the presence of $\mathrm{p} 53$ mutation. On the contrary, $F B X W 7$-mutant CRC showed substantial of phospho-p53(Ser15) induction in the mucosa and early submucosal invasion (Figure 4E, 4F) [mean staining-score; 1.87 (Figure 5A)]. Healthy human small bowel tissue, which was available as an additional control, exhibited a consistent distribution of phosphop53(Ser15) protein in the mucosal lining of the structured bowel wall architecture (Figure 4A, 4B) [mean stainingscore; 1.50 (Figure 5A)]. In general, phospho-p53(Ser15) was enriched in the intestinal crypts, but was much less in the differentiated cell types residing in the villi
(Figure 4B). This may suggest that phospho-p53(Ser15) could be detected in cancer and crypt-based cells which exhibit poor differentiation in contrast to the cells of the villi. Collectively, compared to the negligible expression in control CRC tissues, remarkable accumulation of phospho-p53(Ser15) protein was observed in FBXW7mutant samples.

Even though TP53 mutations have been reported in over $50 \%$ of human tumours [33], it was not possible to profile the TP53 status by molecular methods in the CRCtissues utilized in our previous studies (Ian Tomlinson, personal communication) [28, 29]. However, our data show heterogeneous pattern of p53-staining. There was more p53 staining at the invasion front of CRCs with a small increase (not statistically significant) in total levels of p53 ( $p=0.072)$ among CRC tissues with FBXW7mutation (Figure 6, 6A-6E \& data not shown). Of interest was the fact that the only controlled variable for the wild-type CRC-tissues examined was the presence of intact FBXW7. Similarly, the only controlled variable for the $F B X W 7$-mutated tissues was the presence of an $F B X W 7$ mutation with other cancer mutations remaining unidentified. Regardless of the unknown nature of the non-FBXW7 mutations, the presence of an $F B X W 7$ mutation alone was adequate to give a consistent pattern of phospho-p53(Ser15) induction (mean-range; 1.67-2.33). Statistical analysis confirmed that phopsho-p53(Ser15)induction in $F B X W 7$-mutant tissues was highly significant $(p<0.0005)$ (Figure 5B). Although only a limited number of samples was available, the results pointed towards the suitability of phospho-p53(Ser15) induction as an independent indicative marker of CRC with FBXW7mutation.

\section{Loss of FBXW7 leads to oxaliplatin drug resistance in CRC cells through differential expressions of the TP53 family of transcription factors}

To evaluate the cytotoxicity of oxaliplatin in CRCcells harboring $F B X W 7$-deletion, both $\mathrm{HCT} 116^{\mathrm{FBXW} 7(++)}$ and $\mathrm{HCT} 116^{\mathrm{FBXW} 7(--)}$ cells were treated with increasing concentration of oxaliplatin $(0.05$ to $25.6 \mu \mathrm{M})$, separately, for 3 days. SRB assays were performed, dose-response curves generated and IC50 values calculated. The assay was carried out in triplicate and repeated at least three times. The Student's $t$-test was used to value the statisticalsignificance. The results showed that FBXW7-mutated HCT116 $6^{\mathrm{FBXW} 7(-/-)}$ cells conferred resistance to oxaliplatin drug (Figure 7, 7A-7C). IC50 of HCT116 ${ }^{\mathrm{FBXW} 7(--)}$ for oxaliplatin was almost four times higher than the IC50 of the corresponding $F B X W 7$-wild-type cell line. Indeed, the IC50 of HCT116 $6^{\mathrm{FBXW} 7(+/)}$ cells for oxaliplatin was about $0.6567 \mu \mathrm{M}$ and that of HCT116 $6^{\mathrm{FBXW7-/}}$ cells was about $2.398 \mu \mathrm{M}$ (Figure 7A). The results show that 

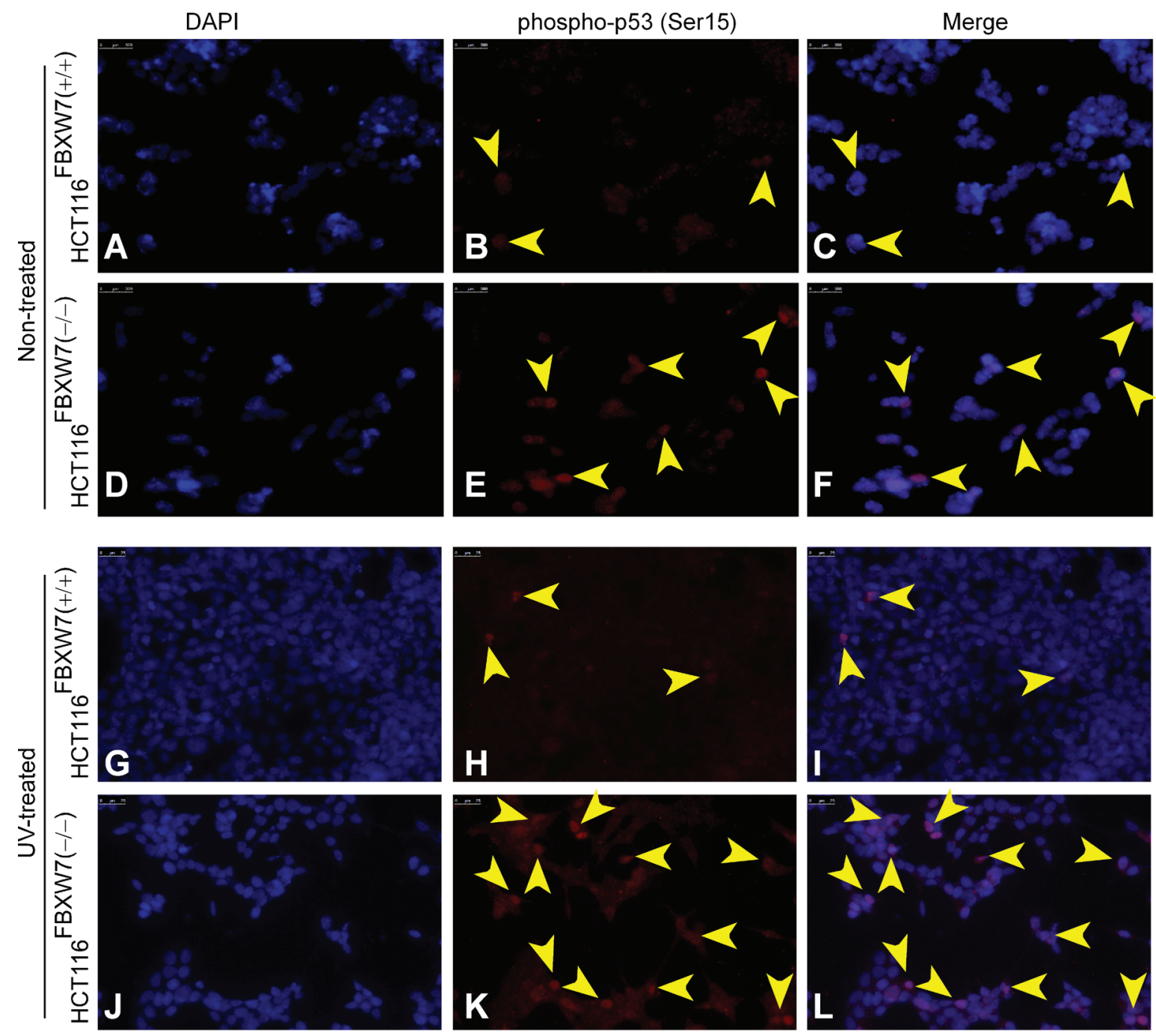

M
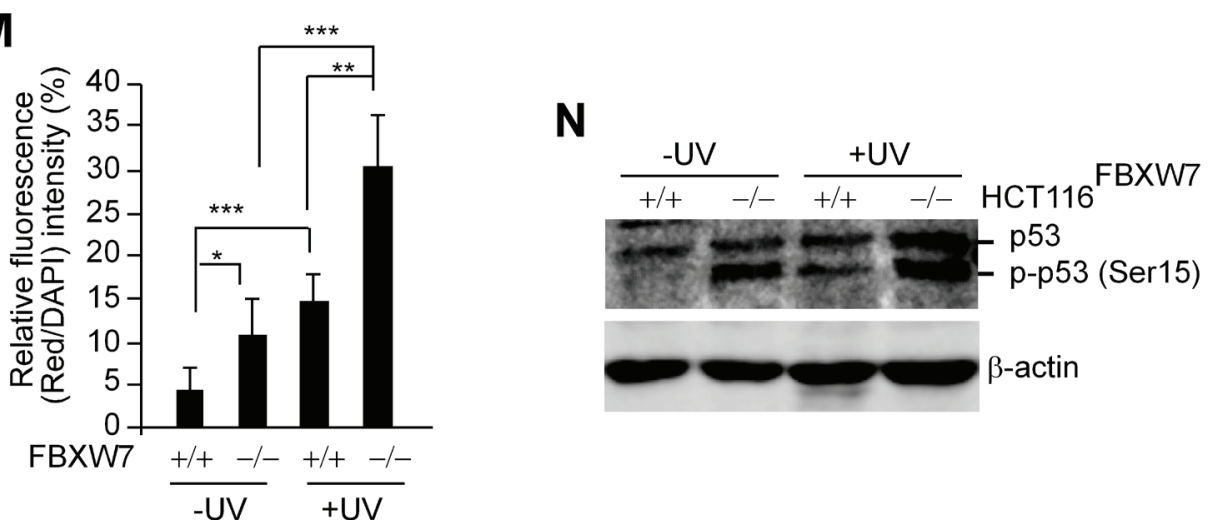

Figure 3: In vitro validation of phospho-p53(Ser15) accumulation in $F B X W 7$-deficient human CRC cells. A-L. Immunofluorescent staining of phospho-p53(Ser15) protein (red) in non-treated (A-F) and $50 \mathrm{~kJ} / \mathrm{m}^{2} \mathrm{UV}$-treated (G-L) HCT116 cells. UV stimulated induction of phospho-p53(Ser15) protein in general (H \& K). In both conditions, FBXW7-deficient cells (E \& K) obtain higher expression levels of phospho-p53(Ser15) than the corresponding control cells (B \& F). Nuclei were visualized with 4', 6-diamidino-2phenylindole (DAPI)-blue fluorescent stain (A, D, G, and J). Overlaid images (C, F, I, and L) showed nuclear localization of phosphop53(Ser15). Arrows indicate phospho-p53(Ser15) distribution. Bars, $25 \mu \mathrm{m}$. Figures are representative of duplicate experiments performed on three separate occasions. M. Quantification analysis of fluorescence intensity of IF images. N. Western blotting analysis of phosphop53(Ser15) expression; untreated and exposed to $50 \mathrm{~kJ} / \mathrm{m}^{2} \mathrm{UV}$. $\beta$-actin served as a loading control. All experiments were repeated at least three times. 

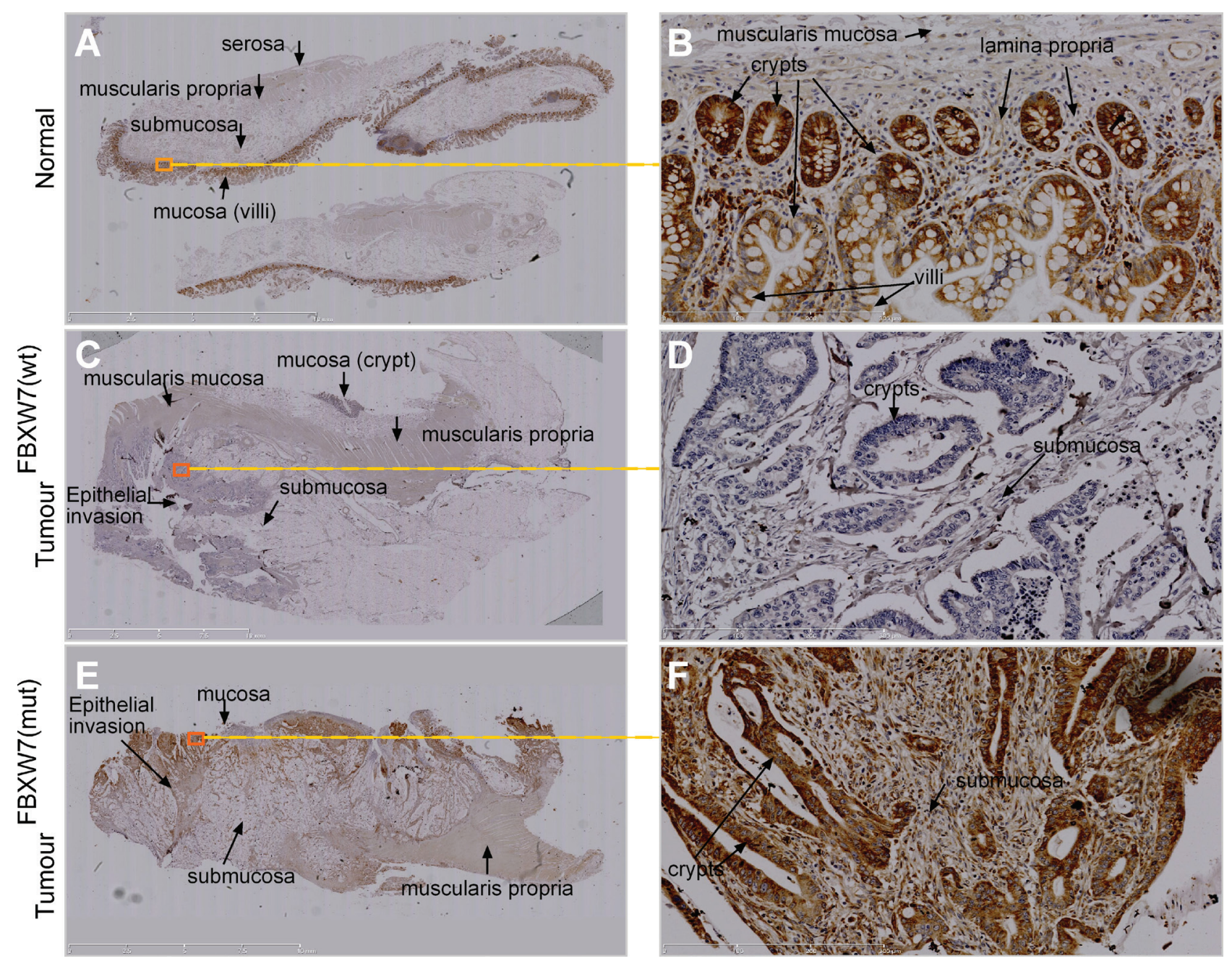

Figure 4: IHC validation of phospho-p53(Ser15) accumulation in FBXW7-mutant human CRC-tissues. A-F. Representative images of chromogenic IHC-staining of paraffin-embedded $F B X W 7$-wild-type (wt) and -mutated (mut) CRC-tissue sections for phospho-p53(Ser15) expression. Specimens of healthy small bowel $(n=1)$ (A and B), $F B X W 7$-wt CRC (C and D), and $F B X W 7$-mut CRC (E and F) show enrichment, annihilation, and remarkable increment of phospho-p53(Ser15) expression. Bars, $50 \mu \mathrm{m}$ (A, C, E); $100 \mu \mathrm{m}(\mathrm{B}, \mathrm{D}, \mathrm{F})$.

FBXW7-deleted cells demonstrated higher tolerance to the effects of oxaliplatin drug (Figure 7,7B, 7C \& data not shown). IC50 values for control HCT116 cells with wildtype FBXW7 are consistent with previously reported values for the same drugs [34]. The data suggest that FBXW7 loss confers HCT116 cells resistance to oxaliplatin.

To address the hypothesis of an existing relationship between mutated-FBXW7 and phopsho-p53(Ser15) protein in response to drug treatment, the expression level of phopsho-p53(Ser15) protein was assessed by Western blotting (Figure 7D). In contrast to UV-irradiation, Western blotting results showed that expression of phospho-p53(Ser15) decreased after oxaliplatin treatment (Figure 7D) in HCT116 FBXw7-/- $^{\mathrm{B}}$ cells. Hence, the decreased phospho-p53(Ser15) on its own might not affect the cell's ability to induce apoptosis. To assess the impact of loss of FBXW7 and TP53-mediated gene expression on $\mathrm{HCT} 116^{\mathrm{FBXW} 7(--)}$ cells behavior, mRNA was isolated from equal numbers of $\mathrm{HCT} 116^{\mathrm{FBXW} 7(++)}$ and HCT116 $6^{\mathrm{FBXW} 7(-))}$ cells (Figure S1). The differential expression of members of the TP53/TP63/TP73 family of transcription factors and apoptosis-related TP53-mediated gene expression (TP53AIP1 and TP53BP2) was analyzed by real-time-PCR [35] (Table S1). The analysis highlights significant up-regulation of TP63 in HCT116 $6^{\mathrm{FBWW} 7(-/)}$ cells while both TP53 and TP73 expression appeared to be down-regulated (Figure 7E). Apoptosis-stimulating protein of TP53AIP1 and TP53BP2 expression was simultaneously down-regulated (Figure 7E). The result may suggest that induction of phopsho-p53(Ser15) by loss of $\mathrm{SCF}^{\mathrm{FBXW} 7}$-E3-ligase activity could contribute to other pathways function to block the p53 activation [27] and consequently decreased efficacy of therapy in chemoresistant CRCs. 
A

\begin{tabular}{|c|c|c|c|c|c|c|c|c|}
\hline & \multirow[t]{2}{*}{$\begin{array}{c}\text { Specimen } \\
\text { number }\end{array}$} & \multicolumn{3}{|c|}{ Scorer1 } & \multicolumn{3}{|c|}{ Scorer2 } & \multirow[t]{2}{*}{$\begin{array}{l}\text { Mean } \\
\text { score }\end{array}$} \\
\hline \multirow{7}{*}{$\begin{array}{c}\text { FBXW7 }^{W T} \\
\text { CRC }\end{array}$} & & 1 & 2 & 3 & 1 & 2 & 3 & \\
\hline & 1 & 0 & 0 & 0 & 0 & 1 & 1 & 0.33 \\
\hline & 2 & 2 & 0 & 1 & 0 & 0 & 1 & 0.67 \\
\hline & 3 & 0 & 0 & 0 & 0 & 1 & 1 & 0.33 \\
\hline & 4 & 0 & 0 & 0 & 0 & 0 & 1 & 0.17 \\
\hline & 5 & 0 & 1 & 0 & 0 & 0 & 0 & 0.17 \\
\hline & 6 & 0 & 0 & 1 & 0 & 0 & 0 & 0.17 \\
\hline \multicolumn{8}{|c|}{ Overall Mean } & 0.31 \\
\hline \multirow{5}{*}{$\begin{array}{c}\text { FBXW7 }^{\text {MUT }} \\
\text { CRC }\end{array}$} & 1 & 3 & 2 & 2 & 3 & 2 & 1 & 2.17 \\
\hline & 2 & 2 & 0 & 2 & 2 & 3 & 1 & 1.67 \\
\hline & 3 & 1 & 3 & 2 & 1 & 2 & 1 & 1.67 \\
\hline & 4 & 1 & 1 & 1 & 2 & 2 & 2 & 1.50 \\
\hline & 5 & 2 & 2 & 3 & 3 & 2 & 2 & 2.33 \\
\hline \multicolumn{8}{|c|}{ Overall Mean } & 1.87 \\
\hline $\begin{array}{l}\text { Healthy } \\
\text { gut }\end{array}$ & 1 & 1 & 2 & 1 & 2 & 2 & 1 & 1.50 \\
\hline
\end{tabular}

B

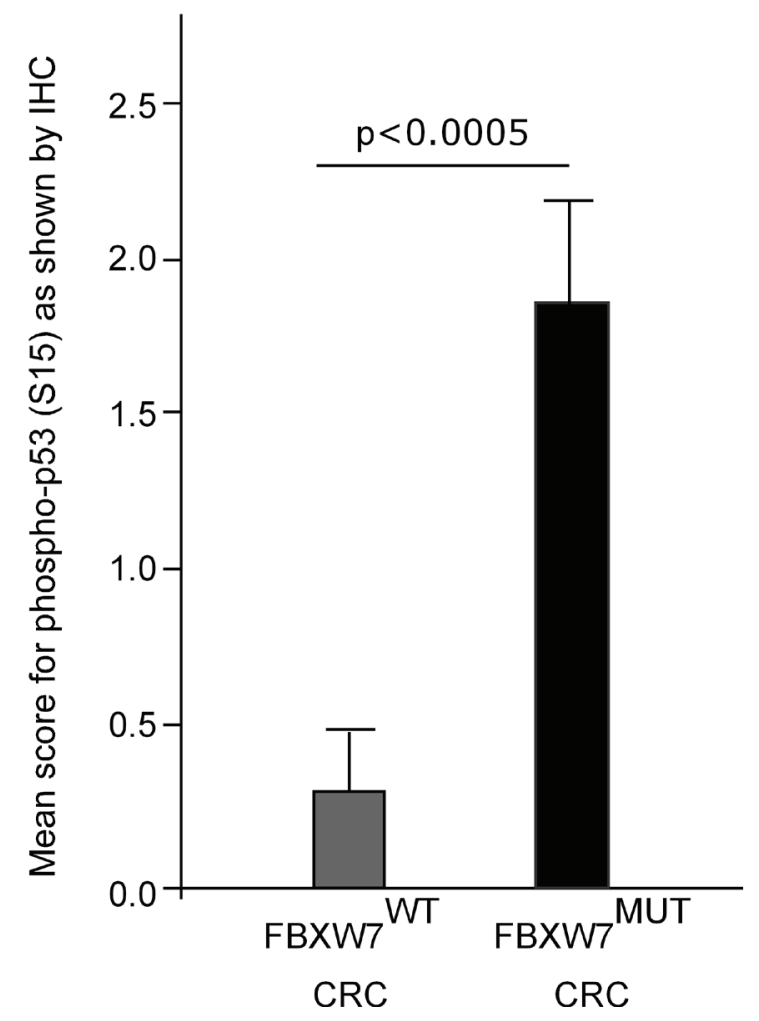

Figure 5: Phospho-p53(Ser15) expression scores in sections from CRC-tissues with and without FBXW7-mutations. A. IHC for human CRC-tissues evaluated semi-quantitatively by two independent observers within 3-microscopic views in the individual slides. Expression scale of the phospho-p53(Ser15) protein was determined by the intensity of the staining, and thus scored using an ordinal scale: $0=$ no staining, $1=$ lowest staining, $2=$ intermediate staining and $3=$ extensive staining. B. $P$ value $(* * * p<0.0005 ;$ mean \pm S.D.; mean for FBXW7 ${ }^{\text {WT }}$ group $=0.31$ with S.D $=0.1945$; and mean for FBXW7 ${ }^{\text {Mut }}$ group $=1.87$ with S.D. $=0.3600$ ) was gained from Student's $t$-test comparing phospho-p53(Ser15) expression in CRC-tissues with and without FBXW7-mutations. 

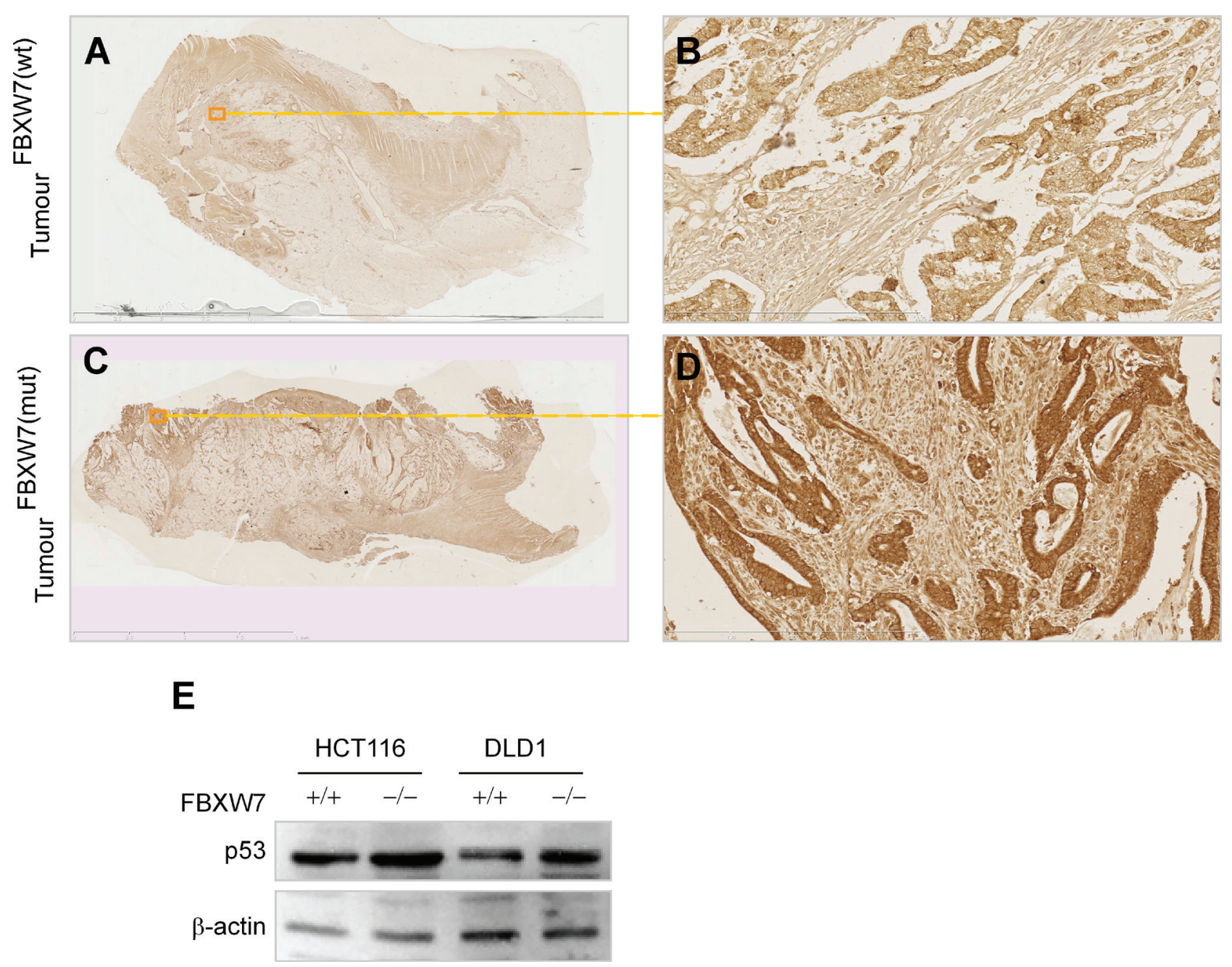

Figure 6: p53 levels remained unchanged in $\boldsymbol{F B} \boldsymbol{X} \boldsymbol{W} 7$-mutant human CRC-tissues. A-D. IHC for p53 in human CRC with $(\mathrm{C}, \mathrm{D})$ and without (A, B) FBXW7 mutations. Boxed line indicates magnified tissue area. Scale bars; $50 \mu \mathrm{m}$. E. Western blotting analysis of p53 expression in HCT116 and DLD-1 cell lines expressing or lacking FBXW7. $\beta$-actin was blotted for loading control. All experiments were repeated for two times.

\section{Phospho-p53(Ser15) may not be a direct target of $\mathrm{SCF}^{\mathrm{FBW}}$-E3 ubiquitin ligase}

In the present studies, we demonstrated through several lines of evidence that FBXW7 ablation in CRC cells results in the accumulation of phospho-p53(Ser15). The mechanism of this is still uncertain. We therefore studied the FBXW7/p53-correlation further to validate the phospho-p53(Ser15) phenomenon. Consistent with the HPKPA results, mutations at either Ser46 (S46A) or Ser392 (S392A) did not stabilize phospho-p53(Ser15) in the presence of FBXW7 (Figure 8A). Western blotting data with cells that overexpress the p53(S15A) mutant protein also determined the anti-phospho-p53(Ser15) antibody specificity (Figure 8A). Furthermore, coexpression of FBXW7 decreased the steady-state levels of p53(wt) (Figure 8B). We next examined whether the FBXW7 protein would bind to $\mathrm{p} 53$ protein and vice versa.
Immunoprecipitation (PI) of either FLAG epitope-tagged p53 or GFP fused-FBXW7 $\alpha$ showed no interaction between these proteins (Figure $8 \mathrm{C}$ ). These data suggest that FBXW7 does not act directly, but indirectly regulates the abundance of phospho-p53(Ser15).

Furthermore, high levels of phosphorylation of p53 at Serine-15(Ser15), modulate cell cycle checkpoint kinase Ataxia-Telangiectasia Mutated (ATM) and Ataxia-Telangiectasia and Rad3-related (ATR) that impede MDM2 binding to p53 and subsequently promote p53 accumulation and activation in response to DNA damage [32, 36]. Phosphorylation of Serine 15 is considered to be an initiating and nucleating event in p53 activation, especially in combination with Ser20 and Thr18 phosphorylation. ATM and ATR kinase however, in turn, activates the effector kinase such Chk2 and ERK to phosphorylate Ser15, along with several other residues in p53 [37-39]. Following p53 Ser15 
A

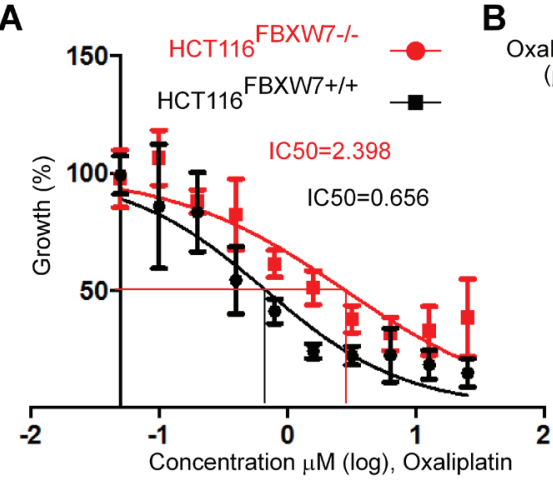

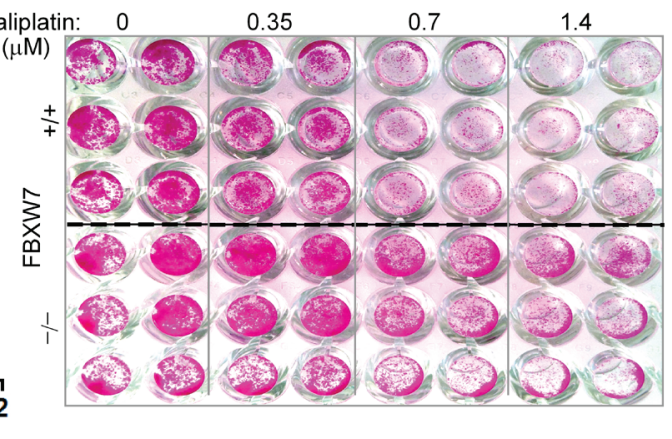

C

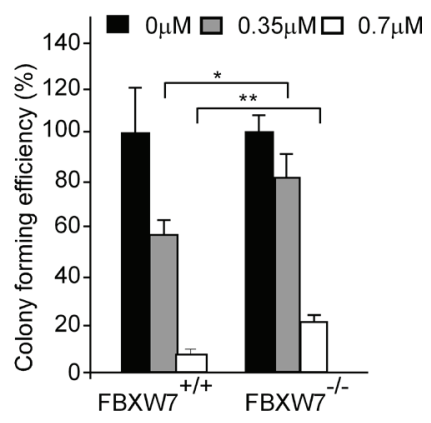

E
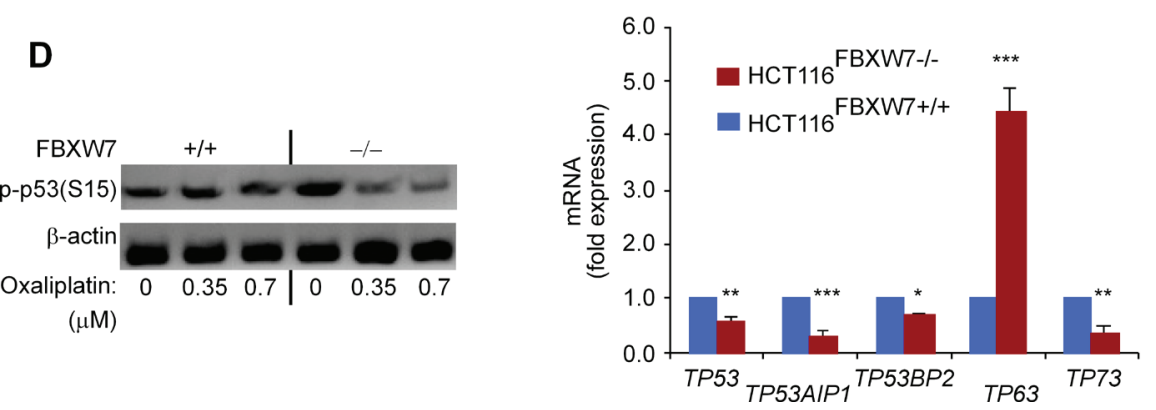

Figure 7: FBXW7 deficiency induces oxaliplatin drug resistance property of HCT116 CRC cells. After starvation overnight, synchronised $\mathrm{HCT} 116^{\mathrm{FBXW} 7(++)}$ and $\mathrm{HCT} 16^{\mathrm{FBXW} 7(-))}$ cells were treated with increasing concentrations of the oxaliplatin; for $72 \mathrm{~h}$, IC50 A. and cell viability B. determined using SRB at $540 \mathrm{~nm}$ in a microplate reader. C. An increased colony forming efficiency of FBXW7-/- HCT116 cells compared with parental FBXW7+/+ HCT116 cells and graphs show mean \pm SEM of assay data, representative of six replicates in three independent experiments $\left({ }^{*} P<0.05, * * P<0.01, * * * P<0.001\right)$. D. phospho-p53(Ser15) protein expression measured at low $(0.35)$ and IC50 dose $(0.7 \mu \mathrm{M})$ oxaliplatin concentration in $\mathrm{HCT} 116^{\mathrm{FBXW} 7(+/)}$ and $\mathrm{HCT} 116^{\mathrm{FBXW}(-(-))}$ cells by Western blotting. E. p53-mediated genes expression was determined by qRT-PCR in HCT116 ${ }^{\mathrm{FBXW} 7(--)}$ cells (red), first normalized to GAPDH followed by normalization to $\mathrm{HCT} 116^{\mathrm{FBXW}(+++)}$ cells (blue). Data are mean $\pm \mathrm{SEM}(* P \leq 0.05 ; * * P 0.01 ; * * * P<0.001)$. Experiments were performed in triplicate for each genotype and repeated at least on three independent occasions.

phosphorylation, protein kinase CK1 can also sequentially phosphorylate Thr18 using the phosphorylated Ser15 as a recognition determinant $[40,41]$. Given these findings, we examined the level of these kinases in both HCT116 and DLD-1 cells lacking and expressing FBXW7. Both Chk2 phosphorylation at Ser516, and Thr68 protein levels were slightly increased in HCT116(-/-) and DLD-1(-/-) cells compared with control $(+/+)$ cells, whereas CK1 $\alpha$ level remarkably increased, especially its long isoform (Figure 8D). Total (phosphorylated and nonphosphorylated) levels of ERK 1/2 remained unchanged (Figure 8D). CK1 $\alpha$ has two alternatively spliced isoforms, one short (known as CK1 $\alpha \mathrm{S}$ ) and one long (known as $\mathrm{CK} 1 \alpha \mathrm{L}$ ). Both human $\mathrm{CK} 1 \alpha$ isoforms contain a common 12-amino-acid short insert located at the carboxyl terminus, whilst CK $1 \alpha \mathrm{L}$ itself includes a 28 -amino-acid long insert (i.e. encoded from exon 5 of CK $1 \alpha \mathrm{L}$ gene) located in the central kinase catalytic domain [42, 43]. Therefore, human CK1 $\alpha$ isoforms are composed of 365 or 337 amino acids due to presence or absence of the exon 5. Consistent with Western blotting data, immunofluorescent staining showed remarkably increased expression levels of a nuclear splice form of CK1 $\alpha$ (Figure 8E). Further analysis, beyond the current scope of this paper, would be required to validate the possibility that FBXW7 could modulate phospho-p53 via targeting $\mathrm{CK} 1 \alpha$ for degradation.

\section{DISCUSSION}

Our experiments do not point to phosphop53(Ser15) as a direct binding substrate for FBXW7 E3ubiquitin ligase degradation. Cellular stress generated by accumulation of FBXW7-substrates (for example, Cyclin $\mathrm{E}$ and c-Myc) may induce the TP53 pathway via phosphop53(Ser15) induction [44, 45]. However, in the colon/ intestine, we and others have shown that expression of c-Myc and Cyclin E were unaffected by loss of intestinal/ colonic-fbxw7 [18, 28, 29, 46]. This could suggest a potential route for FBXW7 regulating phosphorylated p53 protein expression through controlling upstream kinases. Considering the fact that $\mathrm{CK} 1 \alpha$ is an essential 


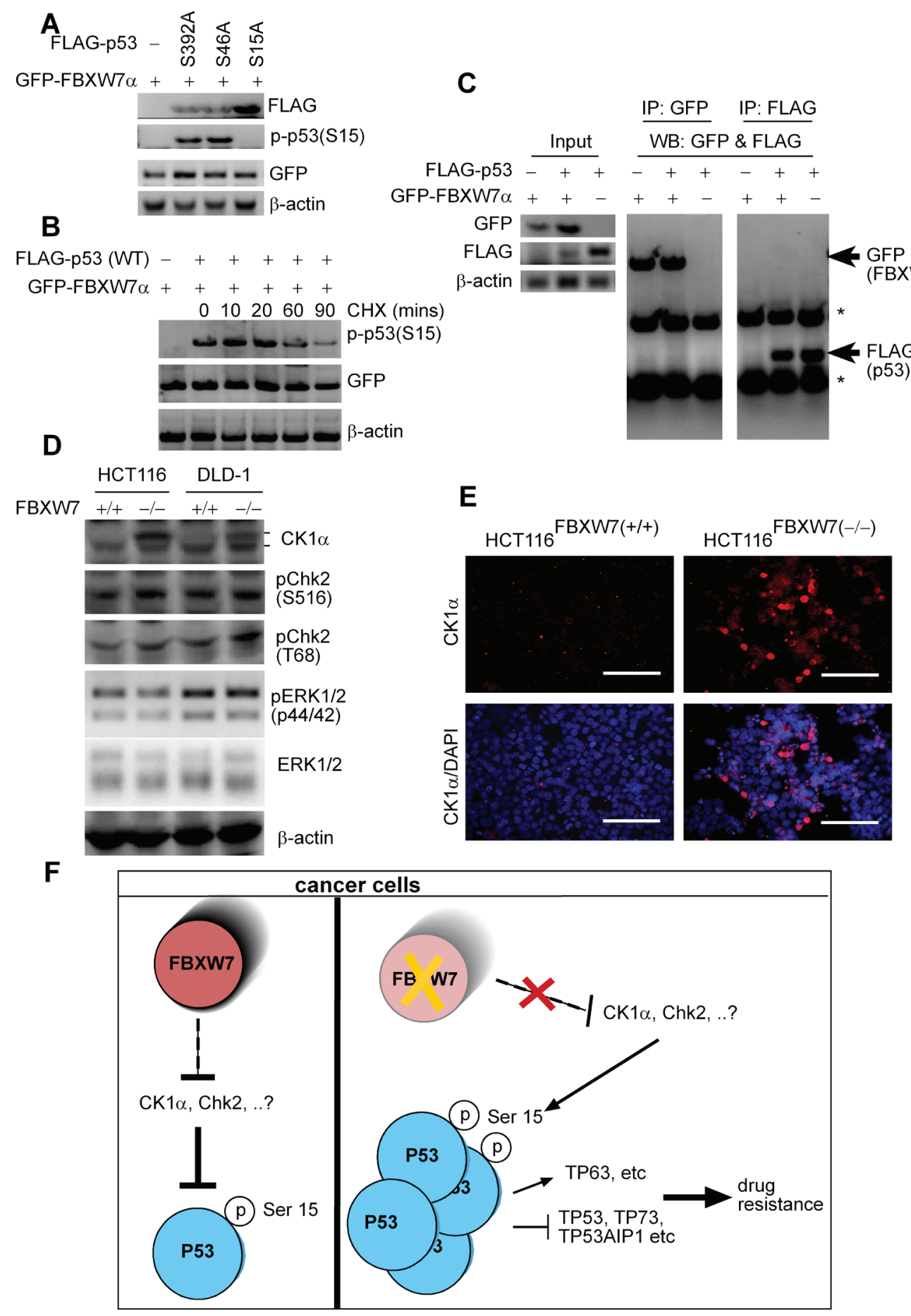

Figure 8: phospho-p53(Ser15) is regulated by FBXW7 but not through direct interaction. A. FLAG-tagged versions of the indicated p53 mutant and GFP-FBXW7 proteins were expressed in HEK293T cells, and lysates were subjected to immunoblotting with anti-FLAG, anti-p-p53(Ser15) and anti-GFP. $\beta$-actin was used as a loading control. B. HEK293T cells were treated with cycloheximide $(\mathrm{CHX})$ for the indicated time points. Lysates were examined by Western blotting anti-p-p53(Ser15) and anti-GFP. $\beta$-actin was used as a loading control. C. Western blot analysis of whole-cell lysates (input) (left-panel) and immunoprecipitates (IP) with GFP (middle-panel) and FLAG-p53 (right-panel) derived from 293T cells transfected with GFP-FBXW7 together with the FLAG-p53 constructs. Thirty hours after transfection, cells were pretreated with $10 \mu \mathrm{M}$ MG132 for $4 \mathrm{~h}$ to block the proteasome pathway before cell collection. Both IPs was probed by anti-GFP and anti-FLAG antibodies simultaneously. D. HCT116 and DLD-1 cells lacking or expressing FBXW7 were subjected to immunoblotting with anti-CK1 $\alpha$, pChk2 (S516), pChk2 (T66), phospho-p44/42 MAPK (pERK1/2) and p44/42 MAPK (ERK1/2). $\beta$-actin was loaded as a loading control. All experiments were repeated at least three times. E. Immunofluorescent staining of anti-CK1 $\alpha$ of HCT116 $6^{\mathrm{FBWW} 7(++)}$ versus HCT116 $6^{\mathrm{FBXW} 7(-+)}$ cells. F. Schematic of molecular changes may occur in the HCT116 $6^{\mathrm{FBXW} 7(--)}$ compared with parental HCT116 ${ }^{\mathrm{FBXW} 7(+/+)}$ cells treated with the oxaliplatin. 
regulator of p53 phosphorylation [40, 41, 47], this study provides the possibility that FBXW7 could modulate phospho-p53 via targeting CK $1 \alpha$ for degradation. Therefore, it could be postulated that loss of FBXW7 could result in CK $1 \alpha$ accrual in vivo, which subsequently leads to increased p53 stabilization and activation. Indeed, we and other recently demonstrated that neither FBXW7 abolishment nor CK1 $\alpha$ deletion in vivo caused immediate intestinal tumour formation [28, 29, 48], possibly due to compensation from the p53 pathway $[16,48]$. Furthermore, we have previously shown an up-regulation of $\beta$-catenin in HCT116(FBXW7-/-) cells [28]. $\beta$-catenin is phosphorylated by CK1 (EMBO J. 2002 Apr 2;21(7):1733-42). Moreover, CK1 $\alpha$ role in malignancy is still ambiguous as it was previously reported as an oncogene [49] and it may also function as a tumour suppressor gene [50]. There are, as yet, no in vivo or in vitro data showing a direct link between CK1 $\alpha$. and p53 Ser15. On the other hand, our data suggest that FBXW7 could be an upstream regulator of p53 and CK $1 \alpha$. Considering the possibility that CK $1 \alpha$ might act as an important co-effector protein linking FBXW7 and other cellular pathways, such as Wnt and p53, in this respect, we may hypothesis a synergistic role for FBXW7 and p53 in suppression of intestinal tumourigenicity and metastasis. Moreover, of interest, are the observations that suggest that wild-type TP53 in tumours may not have the same transcriptional activity often found in their non-transformed counterpart tissues [51]. Hence, further studies are required to prove a possible association between CK1 $\alpha$ and p53(Ser15), and provide significant evidence for CK $1 \alpha$-mediated upregulation phospho-p53(Ser15) in tumours with FBXW7 mutations. Furthermore, these data may also prompt us to reconsider the status of p53 phosphorylation in relation to expression of different isoforms of CK $1 \alpha$ kinase. This may be explained by its diverse roles in different cellular processes $[52,53]$ and by the distinct functions and subcellular locations of its two splicing variants.

Taken together, the results from cytotoxicity and viability assays suggest that loss of FBXW7 function can confer resistance to DNA-damage agent oxaliplatin in CRC cells. FBXW7 might act as a core factor in different mechanisms used by cancer cells to become resistant to chemotherapeutic drugs. Determining these mechanisms of eluding DNA damaging agents, probably through the modulation of $\mathrm{SCF}^{\mathrm{FBXW} 7}$ protein substrate(s), may be crucial for understanding tumour development and its response to current chemotherapy. It has been shown that p53(Ser15) phosphorylation can stimulate p53 activity. In contrast, it was also found that phosphorylation of Serine-15 can block binding of p53 to transcription Factor II D, and inhibit the formation of a DNA promoter complex for transcription [27].
Widely-accepted evidence reveals that tumours exhibit a different type and substantially a greater degree of p53-phosphorylation than normal cells rendering in this way the tumour suppressor nonfunctional [51]. Recently, reports showed that p53 up-regulates FBXW7 $[15,17]$ whereas it represses ZEB family transcriptional regulator (ZEB1 and ZEB2), implicated in epithelialmesenchymal transition (EMT) [54]. Western blotting and immunohistochemistry data did not exhibit statistically significant differences in total p53 protein levels in HCT116 ${ }^{\mathrm{FBXW} 7-/-}$ cells and FBXW7-mutated CRC tissues, compared with parental HCT116 cells which have functional wild-type TP53, and FBXW7-wild-type CRC tissues (Figure 5). There is a lot of research activity as to whether, and how, TP53 family members interact or conflict with each other in apoptosis and tumour suppression [55]. Induction of death of neurons and mouse embryo fibroblasts by p53 requires coalescence of p63 and p73 [56], while not required for the induction of apoptosis in T cells [57]. DeltaNp63 isoform of p63 have been associated with transcriptional activation of ATM and p53 Serine-15 phosphorylation in immortalized human keratinocytes [58]. However, consistent with the recent published data [59], we did not observe any significant changes in levels of ATM kinase from protein extracts isolated from HCT116 and DLD-1 cell lines with FBXW7(-/-) and FBXW7(+/+) alleles in a WB analysis (data not shown). Whether FBXW7-mutation induces EMT via $\mathrm{p} 53 / \mathrm{p} 63 / \mathrm{p} 73$ regulation or vice versa, and provides a possible explanation for the prominent chemoresistance observed in CRC, remains to be elucidated.

Based on our results, further work to investigate the cellular mechanisms implicated in the phospho-p53(Ser15)/ FBXW7 phenomenon are necessary to provide more insight into the underlying mechanisms. Following validation of the phospho-p53(Ser15) protein induction, an enquiry was raised whether such stimulation serves any function within the tumour other than its use as an indicative marker of FBXW7-mutations. Does the phospho-p53(Ser15) induction serve any role in the FBXW7-associated carcinogenesis due to a likely gain/loss/change of P53/ P63/P73 function? Our current data as presented are limited to few tumour specimens. To assess if FBXW7 mutation confers resistance to oxaliplatin relevant to prognosis or treatment response, further studies should be carried out using a large number of patients treated with oxaliplatin.

\section{MATERIALS AND METHODS}

\section{Human colorectal cancer (CRC) tissues}

Paraffin-embedded human colorectal tumour tissue sections, wild-type (FBXW7 ${ }^{\mathrm{WT}} \mathrm{CRC}$ ) and positive for FBXW7-mutation (FBXW7 ${ }^{\text {Mut }} \mathrm{CRC}$ ) were kindly provided by the molecular and population genetics 
laboratory, Wellcome Trust Centre, University of Oxford. The ethical and R\&D approval for use of human tissue was obtained from the local research-ethics committee and Trust R\&D office, in Oxford and Nottingham, as described previously [28].

\section{Human phospho-kinase profiler array (HPKPA)}

In order to identify signaling pathways altered by FBXW7, a human phospho-kinase array kit (R\&D Systems, UK) was used. This consists of a nitrocellulose membrane (Figure 1A) having control antibodies against phosphorylated proteins which are spotted in duplicate. It allows the detection of the relative levels of phosphorylation of protein/kinase phosphorylation sites (antibodies for those sites were selected and spotted in duplicate on nitrocellulose membrane).

Two CRC cell lines (HCT116 and DLD-1 cells) harboring wild-type-FBXW7; $F B X W 7(+/+)$, or inactivated $F B X W 7(-/-)$, were rinsed with PBS, solubilized in the Lysis Buffer supplied with kit and with Halt Protease and EDTA-free Phosphatase Inhibitor Cocktail (100X) was added as 1:100 concentration (Pierce, UK). The lysates were gently rocked at $4^{\circ} \mathrm{C}$ for $30 \mathrm{~min}$ and then centrifuged at 14,000x g. The protein was quantified using the Bradford protein assay (BioRad) and the four different cell lysates were adjusted to $100 \mu \mathrm{g}$ in $1 \mathrm{ml}$ of array buffer supplied with the kit. After blocking the nitrocellulose membrane by rocking in Buffer 1 for 1 hour at room temperature, diluted lysate contain $100 \mu \mathrm{g}$ protein was added and incubated on a rocking platform overnight at $4^{\circ} \mathrm{C}$. Washing with wash buffer was followed by adding the diluted detection antibody cocktail to corresponding part of the membrane and incubation for 2 hours at room temperature on a rocking platform. Another wash was carried and the membranes were incubated with diluted StreptavidinHRP for $30 \mathrm{~min}$ then followed by another washing. The spots were detected using enhanced chemiluminescence (ECL) using the FlourChem FC2 imaging system (Alpha Innotech).

\section{Immunohistochemistry (IHC) and immunofluorescence (IF)}

Paraffin-embedded tissue sections were dewaxed, rehydrated as described $[28,60]$. Peroxidase activity in tissue samples quenched with $1.6 \% \mathrm{H} 2 \mathrm{O} 2(5.33 \mathrm{ml}$ of $30 \% \mathrm{H} 2 \mathrm{O} 2$ [Fisher] added in $94.67 \mathrm{ml}$ of PBS) for $10 \mathrm{~min}$, and sections washed with PBS for $5 \mathrm{~min}$. The specimen region on each section slide circled with a wax PAP-pen, and incubated for $30 \mathrm{~min}$ in $100 \mu \mathrm{l}$ Serum-blocking buffer/ slide $(10 \%[\mathrm{v} / \mathrm{v}]$ normal-serum and $1 \%[\mathrm{w} / \mathrm{v}]$ BovineSerum-Albumin (BSA) in PBS. The sections incubated in primary and biotinylated-secondary-antibody for $1 \mathrm{hr}$ at RT, respectively, followed by PBS wash for $3 \times 3$ mins.
Antibodies freshly prepared by diluting original primary or secondary-antibody appropriately in 1\% BSA/PBS.

Tissues then incubated with Avidin-Biotin-Complex for $30 \mathrm{~min}$ as per manufacturer's instruction, followed by PBS wash for $3 \times 3$ mins. Staining visualized using DAB (3, 3'-diaminobenzidine tetrahydrochloride-dehydrate)-Kit [BioGenex] by chromogenic-reaction with DAB-solution for 2 10 mins according to manufacturer's instruction. Sections monitored microscopically until optimalstaining was achieved, and the DAB-reaction quenched by $\mathrm{dH} 2 \mathrm{O}$-dilution. Slides counterstained with $60 \%$-LightHaematoxylin (v/v). Primary-antibody concentrations were as follows: anti-p53 (1:50; Dako, DO-7-clone) [61] and anti-phospho-p53(Ser15) (1:100; Santa-Cruz; sc-101762) or anti-phospho-p53(Ser15) (1:100; Cell Signaling; D4S1H) [62, 63]. For IF, samples exposed to goat anti-rabbit antibodies conjugated to Alexa-Fluor 594 (1/500; Invitrogen) and/or rabbit anti-mouse antibodies conjugated to Alexa-Fluor 488 (1/500; Invitrogen).

\section{Ultraviolet (UV)-irradiation}

Prior to UV-treatment, the cells were starved in RPMI-medium containing 0.1\%-FBS for $24 \mathrm{hrs}$. UVtreatment performed at $50 \mathrm{~kJ} / \mathrm{m}^{2}$ using SpectrolinkerXL-1000 UV Cross-linker device (Spectromics). Following UV-irradiation, cells incubated for $60 \mathrm{mins}$ in complete-RPMI-medium at $37.5^{\circ} \mathrm{C}, 5 \%-\mathrm{CO}_{2}$.

\section{Cell culture, transfection, and Western blot (WB) analysis}

In vitro analyses were performed by using HCT116 human colon carcinoma cell line deleted for FBXW7 in single (HCT116 $6^{\mathrm{FBXW} 7+/}$ ) or both alleles (HCT116 $6^{\mathrm{FBXW} 7--}$ ) in parallel to the control $\mathrm{HCT} 116^{\mathrm{FBXW} 7+/+}$ cell line, which were extensively characterized in our laboratory and others [19, 20, 28]. Transfection of cell lines HEK293 or HCT116 depending on the experiment with DNA plasmids were carried out using Ployethylenimine (PEI) transfection reagent according to the manufacturer's instructions. The protein was extracted using RIPA buffer, as described previously $[28,60]$. Eluted proteins in SDSloading buffer $(2 \times)$, boiled at $95^{\circ} \mathrm{C}$ for 4 mins, separated on $8 \%$-SDS-PAGE and transferred to polyvinylidenefluoride-membranes. p53 mutants were generated with the QuikChange XL Site-Directed Mutagenesis Kit (Stratagene) according to the manufacturer's instructions. Proteins immunoblotted with primary-antibodies; rabbit phospho-p53(Ser15) (1:1000; Cell Signaling), anti-p53 (1:1000; Dako), anti-phospho-p53(Ser15) (1:1000; SantaCruz), mouse phospho-p53(Ser18) antibody (1:500; R\&D), Fbxw7 (1:500; Bethyl Laboratories), $\beta$-Actin (1/10, 000; Abcam), and phospho-p44/42 MAPK (Erk1/2), p44/42 MAPK (Erk1/2), pChk2 (T68), pChk2 (S516), (all 1:1000) were purchased from Cell Signaling Technologies 
and CKI $\alpha$ from Novus. Secondary-antibodies were HRPlinked goat anti-mouse and goat anti-rabbit antibodies (1/10, 000; Santa-Cruz). Blots were developed using ECL (GE-Healthcare). Experiments repeated on at least two occasions.

\section{Co-Immunoprecipitation (Co-IP)}

HEK293T cells were transfected with plasmids encoding GFP-FBXW7- $\alpha$ [28] and FLAG-p53 (WT) [64]. $30 \mathrm{hrs}$ after transfection, we used $100 \mu \mathrm{l}$ of antiFLAG-conjugated agarose beads (Sigma-Aldrich) to immunoprecipitate p53 or anti-GFP antibody-conjugated agarose beads (MBL International) to immunoprecipitate FBXW7 from whole cell extracts of the HEK293T cells using RIPA buffer $(150 \mathrm{mM} \mathrm{NaCl})$ with protease inhibitors. After IP, the beads were washed thoroughly with RIPA buffer. Immunoprecipitated proteins were eluted using $2 \times$ SDS loading buffer and then boiled at $95^{\circ} \mathrm{C}$ for 4 mins. Denatured proteins were subsequently separated on $10 \%$ SDS PAGE and immunoblotted against anti-GFP and anti-FLAG antibodies as required after transferring to polyvinylidene fluoride membranes as previously described [65]. The experiments were repeated on at least three separate occasions.

\section{Cytotoxicity/viability and colony forming efficiency assays}

Induction of cellular-proliferation through FBXW7-depletion may provide drug-treated cells with survival advantages; therefore prior to treatments, CRC-cells synchronized in G0-phase by serum-free starvation for $18 \mathrm{hrs}$, and then followed $72 \mathrm{hrs}$ with oxaliplatin treatment (Tocris). To determine the celldensity Sulforhodamine-B (SRB) (Sigma) colorimetric assay was performed. In order to fix the cells, $50 \mu \mathrm{l}$ of $30 \%(\mathrm{w} / \mathrm{v})$ cold Trichloroacetic-acid (TCA) added per well and incubated with a final concentration of $10 \%$-TCA for 60 mins at $4^{\circ} \mathrm{C}$. After discarding the solution, the plate washed with distilled water and air dried. Then, the fixed cells dyed with $0.4 \%(\mathrm{w} / \mathrm{v}) \mathrm{SRB}$, in 1\%-acetic-acid for $20 \mathrm{mins}$ at RT. Following fivewashings with $1 \%$-acetic-acid and air-drying, the SRB was dissolved by adding $200 \mu \mathrm{l}$ of $10 \mathrm{mM}$-Trizmabase. Lastly, a microplate-reader (Bio-Rad) measured the absorbance at $540 \mathrm{~nm}$-wavelength [66]. Data were elaborated using Microsoft-Office Excel and GraphPadPrism softwares (http://www.graphpad.com/scientificsoftware/prism/). Colony forming efficiency assay of HCT116(FBXW7+/+), HCT116(FBXW7-/-) cells treated with 2 different concentrations of oxaliplatin for 72 hours for 200 of seeded cells. Images were taken following colonies fixation and crystal violet staining on day 14 of growth and colonies were counted.

\section{qRT-PCR analysis}

For qRT-PCR analysis [28], total RNA was isolated from CRC cells using TRIZOL reagent (SigmaAldrich) and purified using the RNeasy mini kit including DNase (QIAGEN) according to the manufacturer's instructions (Figure S1). cDNA synthesis was performed using Superscript reagents (Invitrogen) according to the manufacturer's instructions. Quantitative real-time PCR was accomplished with SYBR green incorporation (Platinum Quantitative PCR SuperMix-UDG w/ROX; Invitrogen) using an ABI7900HT (Applied Biosystems), and the data were analyzed using SDS 2.3 software (Applied Biosystems). Results were normalized to those obtained with $G A P D H$, and data are presented as fold induction/repression over parental cells. Details of primers used are shown in Table S1. All assays were performed in triplicate at least three times.

\section{Measuring the level of fluorescence using ImageJ}

For quantification of fluorescence intensity, images of IFs were converted into binary images using the ImageJ program (http://rsbweb.nih.gov/ij/download.html) for determining/measuring the level of fluorescence in a selected area. We selected the area of the image with Redfluorescent (stained with phospho-p53 antibody) first while set measurements for area, integrated density and mean. Basically with selecting "measure" it provide values. Once measurement for red-fluorescent finished, DAPI (bluefluorescent) were selected. We have also selected area with no fluorescent as background. We have selected 5 areas per slide. We used the following formula to calculate the corrected total cell fluorescence (CTCF). CTCF = Integrated Density - (Area of selected fluorescent $\times$ Mean fluorescence of background readings). Then, we have calculated the ratio of average values obtained between p53(Ser15)/DAPI (red/blue) for each condition. We made a graph and showed $\%$ of their relative of fluorescence.

\section{Statistical analysis}

Statistical analysis was undertaken using SPSS 15.0 software. All evaluations were done using the unpaired two-tailed Student's $t$-test. For IHC analysis, the chisquare test was used and $p<0.05$ was considered to indicate a significant difference.

\section{Supporting information}

Supplemental Information contains Supplementary Figure 1, Legend and Supplementary Tables 1, can be found with this article online at Oncotarget website. 


\section{ACKNOWLEDGMENTS}

HCT116 and DLD-1 CRC cells harboring deletion of FBXW7 were a kind gift from A. Balmain (University of California, San Francisco, San Francisco, CA) and B. Vogelstein (Ludwig Center, Johns Hopkins University, Baltimore, MD). We thank B. Spencer-Dene and A. Grabowska for reading the manuscript and $\mathrm{H}$. Davis and R. Muraleedharan for technical advice, and the fantastic fundraising efforts of Charlotte Sims and her family in memory of Daz Sims to support the work in our laboratory. This study was supported by Cancer Research UK, research project A9275 to A. S. Nateri.

\section{CONFLICTS OF INTEREST}

The authors declare that there are no conflicts of interest.

\section{REFERENCES}

1. Wang Z, Inuzuka H, Zhong J, Wan L, Fukushima H, Sarkar FH, Wei W. Tumour suppressor functions of FBW7 in cancer development and progression. FEBS letters. 2012; 586:1409-1418.

2. Batinac T, Gruber F, Lipozencic J, Zamolo-Koncar G, Stasic A, Brajac I. Protein p53-structure, function, and possible therapeutic implications. Acta dermatovenerologica Croatica: ADC. 2003; 11:225-230.

3. Welcker M, Clurman BE. FBW7 ubiquitin ligase: a tumour suppressor at the crossroads of cell division, growth and differentiation. Nat Rev Cancer. 2008; 8:83-93.

4. Rivlin N, Brosh R, Oren M, Rotter V. Mutations in the p53 Tumour Suppressor Gene: Important Milestones at the Various Steps of Tumourigenesis. Genes \& cancer. 2011; 2:466-474.

5. Markowitz SD, Bertagnolli MM. Molecular origins of cancer: Molecular basis of colorectal cancer. The New England journal of medicine. 2009; 361:2449-2460.

6. Wood LD, Parsons DW, Jones S, Lin J, Sjoblom T, Leary RJ, Shen D, Boca SM, Barber T, Ptak J, et al. The genomic landscapes of human breast and colorectal cancers. Science. 2007; 318:1108-1113.

7. Sjoblom T, Jones S, Wood LD, Parsons DW, Lin J, Barber TD, Mandelker D, Leary RJ, Ptak J, Silliman N, et al. The consensus coding sequences of human breast and colorectal cancers. Science. 2006; 314:268-274.

8. Wang Z, Inuzuka H, Fukushima H, Wan L, Gao D, Shaik S, Sarkar FH, Wei W. Emerging roles of the FBW7 tumour suppressor in stem cell differentiation. EMBO reports. 2012; 13:36-43.

9. Cheng Y, Li G. Role of the ubiquitin ligase Fbw7 in cancer progression. Cancer metastasis reviews. 2012; 31:75-87.
10. Kitagawa K, Kotake Y, Kitagawa M. Ubiquitin-mediated control of oncogene and tumour suppressor gene products. Cancer science. 2009; 100:1374-1381.

11. Onoyama I, Nakayama KI. Fbxw7 in cell cycle exit and stem cell maintenance: insight from gene-targeted mice. Cell cycle (Georgetown, Tex). 2008; 7:3307-3313.

12. Tan Y, Sangfelt O, Spruck C. The Fbxw $7 /$ hCdc4 tumour suppressor in human cancer. Cancer letters. 2008; 271:1-12.

13. Wang Z, Fukushima H, Gao D, Inuzuka H, Wan L, Lau AW, Liu P, Wei W. The two faces of FBW7 in cancer drug resistance. BioEssays: news and reviews in molecular, cellular and developmental biology. 2011; 33:851-859.

14. Davis RJ, Welcker M, Clurman BE. Tumour Suppression by the Fbw7 Ubiquitin Ligase: Mechanisms and Opportunities. Cancer Cell. 2014; 26:455-464.

15. Yokobori T, Mimori K, Iwatsuki M, Ishii H, Onoyama I, Fukagawa T, Kuwano H, Nakayama KI, Mori M. p53Altered FBXW7 expression determines poor prognosis in gastric cancer cases. Cancer Res. 2009; 69:3788-3794.

16. Grim JE, Knoblaugh SE, Guthrie KA, Hagar A, Swanger J, Hespelt J, Delrow JJ, Small T, Grady WM, Nakayama KI, et al. Fbw7 and p53 cooperatively suppress advanced and chromosomally unstable intestinal cancer. Molecular and cellular biology. 2012; 32:2160-2167.

17. Matsumoto A, Onoyama I, Nakayama KI. Expression of mouse Fbxw7 isoforms is regulated in a cell cycle- or p53-dependent manner. Biochemical and biophysical research communications. 2006; 350:114-119.

18. Mao JH, Perez-Losada J, Wu D, Delrosario R, Tsunematsu R, Nakayama KI, Brown K, Bryson S, Balmain A. Fbxw7/Cdc4 is a p53-dependent, haploinsufficient tumour suppressor gene. Nature. 2004; 432:775-779.

19. Rajagopalan H, Jallepalli PV, Rago C, Velculescu VE, Kinzler KW, Vogelstein B, Lengauer C. Inactivation of hCDC4 can cause chromosomal instability. Nature. 2004; 428:77-81.

20. Mao JH, Kim IJ, Wu D, Climent J, Kang HC, DelRosario R, Balmain A. FBXW7 targets mTOR for degradation and cooperates with PTEN in tumour suppression. Science. 2008; 321:1499-1502.

21. Wang Y, Liu Y, Lu J, Zhang P, Wang Y, Xu Y, Wang Z, Mao JH, Wei G. Rapamycin inhibits FBXW7 loss-induced epithelial-mesenchymal transition and cancer stem cell-like characteristics in colorectal cancer cells. Biochemical and biophysical research communications. 2013; 434:352-356.

22. Wertz IE, Kusam S, Lam C, Okamoto T, Sandoval W, Anderson DJ, Helgason E, Ernst JA, Eby M, Liu J, et al. Sensitivity to antitubulin chemotherapeutics is regulated by MCL1 and FBW7. Nature. 2011; 471:110-114.

23. Inuzuka $\mathrm{H}$, Shaik $\mathrm{S}$, Onoyama $\mathrm{I}$, Gao $\mathrm{D}$, Tseng $\mathrm{A}$, Maser RS, Zhai B, Wan L, Gutierrez A, Lau AW, et al. $\mathrm{SCF}(\mathrm{FBW} 7)$ regulates cellular apoptosis by targeting MCL1 for ubiquitylation and destruction. Nature. 2011; 471:104-109. 
24. Traven A, Heierhorst J. SQ/TQ cluster domains: concentrated ATM/ATR kinase phosphorylation site regions in DNA-damage-response proteins. BioEssays: news and reviews in molecular, cellular and developmental biology. 2005; 27:397-407.

25. Vousden KH, Lu X. Live or let die: the cell's response to p53. Nat Rev Cancer. 2002; 2:594-604.

26. Minamoto T, Buschmann T, Habelhah H, Matusevich E, Tahara H, Boerresen-Dale AL, Harris C, Sidransky D, Ronai Z. Distinct pattern of p53 phosphorylation in human tumours. Oncogene. 2001; 20:3341-3347.

27. Pise-Masison CA, Radonovich M, Sakaguchi K, Appella E, Brady JN. Phosphorylation of p53: a novel pathway for p53 inactivation in human T-cell lymphotropic virus type 1-transformed cells. Journal of virology. 1998; 72:6348-6355.

28. Babaei-Jadidi R, Li N, Saadeddin A, Spencer-Dene B, Jandke A, Muhammad B, Ibrahim EE, Muraleedharan R, Abuzinadah M, Davis H, et al. FBXW7 influences murine intestinal homeostasis and cancer, targeting Notch, Jun, and DEK for degradation. J Exp Med. 2011; 208:295-312.

29. Sancho R, Jandke A, Davis H, Diefenbacher ME, Tomlinson I, Behrens A. F-box and WD repeat domaincontaining 7 regulates intestinal cell lineage commitment and is a haploinsufficient tumour suppressor. Gastroenterology. 2010; 139:929-941.

30. Sluss HK, Armata H, Gallant J, Jones SN. Phosphorylation of Serine 18 regulates distinct p53 functions in mice. Molecular and cellular biology. 2004; 24:976-984.

31. Ouhtit A, Nakazawa H, Armstrong BK, Kricker A, Tan E, Yamasaki H, English DR. UV-radiation-specific p53 mutation frequency in normal skin as a predictor of risk of basal cell carcinoma. Journal of the National Cancer Institute. 1998; 90:523-531.

32. Tibbetts RS, Brumbaugh KM, Williams JM, Sarkaria JN, Cliby WA, Shieh SY, Taya Y, Prives C, Abraham RT. A role for ATR in the DNA damage-induced phosphorylation of p53. Genes \& development. 1999; 13:152-157.

33. Olivier M, Hollstein M, Hainaut P. TP53 mutations in human cancers: origins, consequences, and clinical use. Cold Spring Harb Perspect Biol. 2010; 2:a001008.

34. Na YS, Kim SM, Jung KA, Yang SJ, Hong YS, Ryu MH, Ro S, Cho DH, Kim JC, Jin DH, et al. Effects of the HDAC inhibitor CG2 in combination with irinotecan, 5-fluorouracil, or oxaliplatin on HCT116 colon cancer cells and xenografts. Oncology reports. 2010; 24:1509-1514.

35. Rowley JW, Oler AJ, Tolley ND, Hunter BN, Low EN, Nix DA, Yost CC, Zimmerman GA, Weyrich AS. Genome-wide RNA-seq analysis of human and mouse platelet transcriptomes. Blood. 2011; 118:e101-111.

36. Shieh SY, Ahn J, Tamai K, Taya Y, Prives C. The human homologs of checkpoint kinases Chk1 and Cds1 (Chk2) phosphorylate p53 at multiple DNA damage-inducible sites. Genes \& development. 2000; 14:289-300.
37. Zhao H, Traganos F, Darzynkiewicz Z. Phosphorylation of p53 on Ser15 during cell cycle caused by Topo I and Topo II inhibitors in relation to ATM and Chk2 activation. Cell cycle (Georgetown, Tex). 2008; 7:3048-3055.

38. She QB, Chen N, Dong Z. ERKs and p38 kinase phosphorylate p53 protein at Serine 15 in response to UV radiation. J Biol Chem. 2000; 275:20444-20449.

39. Melnikova VO, Santamaria AB, Bolshakov SV, Ananthaswamy HN. Mutant p53 is constitutively phosphorylated at Serine 15 in UV-induced mouse skin tumours: involvement of ERK1/2 MAP kinase. Oncogene. 2003; 22:5958-5966.

40. Sakaguchi K, Saito S, Higashimoto Y, Roy S, Anderson CW, Appella E. Damage-mediated phosphorylation of human 53 threonine 18 through a cascade mediated by a casein 1-like kinase. Effect on Mdm2 binding. J Biol Chem. 2000; 275:9278-9283.

41. Venerando A, Marin O, Cozza G, Bustos VH, Sarno S, Pinna LA. Isoform specific phosphorylation of p53 by protein kinase CK1. Cell Mol Life Sci. 2010; 67:1105-1118.

42. Tapia C, Featherstone T, Gomez C, Taillon-Miller P, Allende CC, Allende JE. Cloning and chromosomal localization of the gene coding for human protein kinase CK1. FEBS letters. 1994; 349:307-312.

43. Yong TJ, Gan YY, Toh BH, Sentry JW. Human CKIalpha(L) and CKIalpha(S) are encoded by both 2.4- and 4. 2-kb transcripts. the longer containing multiple RNAdestablising elements. Biochimica et biophysica acta. 2000; 1492:425-433.

44. Minella AC, Swanger J, Bryant E, Welcker M, Hwang H, Clurman BE. p53 and p21 form an inducible barrier that protects cells against cyclin E-cdk2 deregulation. Current biology: CB. 2002; 12:1817-1827.

45. Nieminen AI, Eskelinen VM, Haikala HM, Tervonen TA, Yan Y, Partanen JI, Klefstrom J. Myc-induced AMPKphospho p53 pathway activates Bak to sensitize mitochondrial apoptosis. Proc Natl Acad Sci U S A. 2013; 110:E1839-1848.

46. Davis H, Lewis A, Behrens A, Tomlinson I. Investigation of the atypical FBXW7 mutation spectrum in human tumours by conditional expression of a heterozygous propellor tip missense allele in the mouse intestines. Gut. 2014; 63:792-799.

47. Huart AS, MacLaine NJ, Meek DW, Hupp TR. CK1alpha plays a central role in mediating MDM2 control of p53 and E2F-1 protein stability. J Biol Chem. 2009; 284:32384-32394.

48. Elyada E, Pribluda A, Goldstein RE, Morgenstern Y, Brachya G, Cojocaru G, Snir-Alkalay I, Burstain I, HaffnerKrausz R, Jung S, et al. CKIalpha ablation highlights a critical role for p53 in invasiveness control. Nature. 2011; 470:409-413. 
49. Bidere N, Ngo VN, Lee J, Collins C, Zheng L, Wan F, Davis RE, Lenz G, Anderson DE, Arnoult D, et al. Casein kinase 1alpha governs antigen-receptor-induced NF-kappaB activation and human lymphoma cell survival. Nature. 2009; 458:92-96.

50. Sinnberg T, Menzel M, Kaesler S, Biedermann T, Sauer B, Nahnsen S, Schwarz M, Garbe C, Schittek B. Suppression of casein kinase 1alpha in melanoma cells induces a switch in beta-catenin signaling to promote metastasis. Cancer Res. 2010; 70:6999-7009.

51. Matsumoto M, Furihata M, Ohtsuki Y. Posttranslational phosphorylation of mutant p53 protein in tumour development. Medical molecular morphology. 2006; 39:79-87.

52. Knippschild U, Gocht A, Wolff S, Huber N, Lohler J, Stoter M. The casein kinase 1 family: participation in multiple cellular processes in eukaryotes. Cellular signalling. 2005; 17:675-689.

53. Knippschild U, Wolff S, Giamas G, Brockschmidt C, Wittau M, Wurl PU, Eismann T, Stoter M. The role of the casein kinase 1 (CK1) family in different signaling pathways linked to cancer development. Onkologie. 2005; 28:508-514.

54. Kim T, Veronese A, Pichiorri F, Lee TJ, Jeon YJ, Volinia S, Pineau P, Marchio A, Palatini J, Suh SS, et al. p53 regulates epithelial-mesenchymal transition through microRNAs targeting ZEB1 and ZEB2. J Exp Med. 2011; 208:875-883.

55. Benchimol S. p53 - an examination of sibling support in apoptosis control. Cancer Cell. 2004; 6:3-4.

56. Flores ER, Tsai KY, Crowley D, Sengupta S, Yang A, McKeon F, Jacks T. p63 and p73 are required for p53-dependent apoptosis in response to DNA damage. Nature. 2002; 416:560-564.

57. Senoo M, Manis JP, Alt FW, McKeon F. p3 and p73 are not required for the development and p53-dependent apoptosis of T cells. Cancer Cell. 2004; 6:85-89.

58. Craig AL, Holcakova J, Finlan LE, Nekulova M, Hrstka R, Gueven N, DiRenzo J, Smith G, Hupp TR, Vojtesek B.
DeltaNp63 transcriptionally regulates ATM to control p53 Serine-15 phosphorylation. Molecular cancer. 2010; 9:195.

59. Zhao J, Tang J, Men W, Ren K. FBXW7-mediated degradation of CCDC6 is impaired by ATM during DNA damage response in lung cancer cells. FEBS letters. 2012; 586:4257-4263.

60. Ibrahim EE, Babaei-Jadidi R, Saadeddin A, SpencerDene B, Hossaini S, Abuzinadah M, Li N, Fadhil W, Ilyas M, Bonnet D, et al. Embryonic NANOG activity defines colorectal cancer stem cells and modulates through AP1- and TCF-dependent mechanisms. Stem cells (Dayton, Ohio). 2012; 30:2076-2087.

61. Ramael M, Lemmens G, Eerdekens C, Buysse C, Deblier I, Jacobs W, van Marck E. Immunoreactivity for $\mathrm{p} 53$ protein in malignant mesothelioma and non-neoplastic mesothelium. The Journal of pathology. 1992; 168:371-375.

62. Segreto HR, Oshima CT, Franco MF, Silva MR, Egami MI, Teixeira VP, Segreto RA. Phosphorylation and cytoplasmic localization of MAPK p38 during apoptosis signaling in bone marrow granulocytes of mice irradiated in vivo and the role of amifostine in reducing these effects. Acta histochemica. 2011; 113:300-307.

63. Le Floch N, Rincheval V, Ferecatu I, Ali-Boina R, Renaud F, Mignotte B, Vayssiere JL. The p76(Rb) and $\mathrm{p} 100(\mathrm{Rb})$ truncated forms of the $\mathrm{Rb}$ protein exert antagonistic roles on cell death regulation in human cell lines. Biochemical and biophysical research communications. 2010; 399:173-178.

64. Gjoerup O, Zaveri D, Roberts TM. Induction of p53independent apoptosis by simian virus 40 small $\mathrm{t}$ antigen. Journal of virology. 2001; 75:9142-9155.

65. Nateri AS, Riera-Sans L, Da Costa C, Behrens A. The ubiquitin ligase SCFFbw7 antagonizes apoptotic JNK signaling. Science. 2004; 303:1374-1378.

66. Vichai V, Kirtikara K. Sulforhodamine B colorimetric assay for cytotoxicity screening. Nature protocols. 2006; 1:1112-1116. 